\title{
Effectiveness of Antiemetics in the Management of Chemotherapy-induced Nausea and Vomiting in Cancer Patients Following Chemotherapy Guidelines
}

\begin{abstract}
GEETHA KANDASAMY, P. SIVANANDY ${ }^{1}$, M. KHOBRANI, DALIA ALMAGHASLAH, MONA ALMANASEF, RAJALAKSHIMI VASUDEVAN, MAHESWARI CHINNADHURAI ${ }^{2}$, NAYANA HONEY ${ }^{3}$

Department of Clinical Pharmacy, College of Pharmacy, King Khalid University, Abha-61441, Kingdom of Saudi Arabia, ${ }^{1}$ Department of Pharmacy Practice, School of Pharmacy, International Medical University, Kuala Lumpur, Malaysia, ${ }^{2}$ Department of Pharmacy Practice, College of Pharmacy, Shaqra University, Al- Dawadmi Campus, Kingdom of Saudi Arabia, ${ }^{3}$ Department of Pharmacy Practice, KMCH College of Pharmacy, Coimbatore-641 048, India
\end{abstract}

Kandasamy et al: : Antiemetics Guidelines Consistency in CINV

\begin{abstract}
Cancer chemotherapy might in turn induce nausea and vomiting as a side effect, which impairs patients' quality of life and adherence to medications. Inconsistent following of antiemetic guidelines among the physician could significantly increase the incidence of chemotherapy-induced nausea and vomiting in cancer patients. This study was aimed to evaluate antiemetic guidelines consistency and the effectiveness of antiemetics in controlling chemotherapy-induced nausea and vomiting in cancer patients. This study was carried out among patients treated with low emetogenic chemotherapy to highly emetogenic chemotherapy who had completed their first chemotherapy cycle at the department of Haemato-Oncology. Among the 1725 adult patients enrolled in the study, only $60 \%$ received cancer medications according to the standard guidelines and $40 \%$ did not. Fifty-two percent patients were under highly emetogenic chemotherapy regimen, $36 \%$ were in moderate emetogenic chemotherapy and $12 \%$ in low emetogenic chemotherapy regimen. Antiemetic drug was given adjunct to cancer chemotherapy, in which $82 \%$ of patients were found to have no emesis in all highly emetogenic chemotherapy, moderate emetogenic chemotherapy and low emetogenic chemotherapy cohorts while $8.35 \%$ with acute, $7.65 \%$ with delayed, $2.32 \%$ with acute and delayed emesis were observed in highly emetogenic chemotherapy cohort. A $10 \%$ failure rate was observed in the treatment groups even though the guidelines were followed to treat chemotherapy-induced nausea and vomiting. In addition to implementing anticancer treatment guidelines, strict monitoring of patients and follow up is very essential to prevent treatment failure in chemotherapy-induced nausea and vomiting.
\end{abstract}

Key words: Oncology, chemotherapy, supportive care, malignancy, antiemetics, guidelines

Cancer (malignancy) is a common term for the group of more than 150 diseases characterized by uncontrolled growth and spread of abnormal cells ${ }^{[1]}$. There are more than 100 types of cancer and the types of cancer are determined by what type of cells begins to grow abnormally and where in the body the abnormal growth occurs, e.g., breast cancer, lung cancer, colon cancer, rectal cancer, endometrial cancer, ovarian cancer, prostate cancer, and skin cancer. Symptoms of cancer depend upon the specific type and of cancer. Treatments of cancer are chemotherapy, radiation and surgery ${ }^{[2]}$. The main causes of cancers are tobacco usage, obesity, diet, lack of physical activity, alcohol, infections (20\%) such as hepatitis B, C, human papilloma virus, exposure to ionizing radiation, pollutants and partly by changing the genes of cell[ ${ }^{[3]}$.

*Address for correspondence

E-mail: geethpharma@gmail.com

July-August 2019

Indian Journal of Pharmaceutical Sciences
According to the American Cancer Society, there are seven warning signs of cancer that has to be monitored carefully for the early diagnosis of cancer, it includes change in bowel habits, a sore that does not heal, unusual discharge or bleeding, thickening or lump in the breast or elsewhere, change in digestion, or difficulty in swallowing, apparent change in a mole and distressing cough ${ }^{[1,4]}$. The common symptoms of cancer are fatigue, anorexia, weight loss, anemia, marked

This is an open access article distributed under the terms of the Creative Commons Attribution-NonCommercial-ShareAlike 3.0 License, which allows others to remix, tweak, and build upon the work non-commercially, as long as the author is credited and the new creations are licensed under the identical terms

Accepted 26 June 2019

Revised 30 March 2019

Received 24 December 2018

Indian J Pharm Sci 2019;81(4):757-765 
weakness, alterations in taste perception, leucopenia, thrombocytopenia, and infection ${ }^{[1]}$.

In cancer management, early diagnosis and start of cancer treatment are warranted. There are several drugs discovered and available for the treatment of different cancer types, however some drugs are preferred to use as monotherapy and some are used along with other agents as combination therapy. Some drugs are given orally and some are given by the intravenous (iv) route. Example for drugs that are given as a single iv injection are cisplatin, dacarbazine, carmustine, mechlorethamine, streptozotocin, oxaliplatin, cytarabine, carboplatin, ifosfamide, doxorubicin, daunorubicin, docetaxel, paclitaxel, mitoxantrone, etoposide, topotecan, 5-fluorouracil and methotrexate; and as a single oral dose are procarbazine, hexamethylmelamine cyclophosphamide, vinorelbine, etoposide, capecitabine, and fludarabine $e^{[5-7]}$.

Chemotherapy-induced nausea and vomiting (CINV) is the most feared common side effect linked with cancer therapy ${ }^{[8]}$. Nausea is an unlikable wave like symptom occur in the back of the throat and or the epigastria that may wind up in vomiting. Vomiting is a self-limited, short-lived, persuasive expulsion of the contents present in stomach, duodenum and jejunum through oral cavity ${ }^{[9]}$. More than $80 \%$ patients who receive cancer chemotherapy experience nausea and vomiting (NV). CINV adversely affects patients quality of life (QoL), causes serious metabolic complications, and leads to poor compliance to anticancer regimen ${ }^{[10]}$.

Frequent vomiting associated with cancer chemotherapy causes loss of body fluids and electrolyte imbalance. CINV also reduces the tendency to eat or drink anything, and affect physical, emotional and social wellbeing of cancer patients ${ }^{[11]}$. If this condition continues it might cause fatigue, anxiety, lack of concentration, impairment of wound healing, weight loss, lack of appetite and it would became a serious health problem very quickly ${ }^{[12,13]}$.

Several classifications of CINV are widely used including acute, delayed, anticipatory, breakthrough and refractory. Acute CINV starts during the first $24 \mathrm{~h}$, usually within the first few minutes to hours after the administration of chemotherapy. Delayed CINV develops in patients $24 \mathrm{~h}$ after the administration of chemotherapy. It may continue up to $6 \mathrm{~d}$ and it commonly occurs with cisplatin, carboplatin, cyclophosphamide and anthracyclines. Anticipatory NV starts in patients before receiving chemotherapy due to a prior adverse experience with chemotherapy. Breakthrough CINV occurs despite prophylactic treatment. Refractory NV occur throughout subsequent cycles of chemotherapy when antiemetic prophylaxis is unsuccessful in earlier cycles. The different grading of CINV and the risk category of anticancer drugs are presented in Tables $1^{[13]}$ and $2^{[14]}$, respectively.

Based on this risk criterion there are specific strategies available under chemotherapy guidelines. There are several guidelines commonly used nowadays, such as the National Comprehensive Cancer Network (NCCN), the American Society of Clinical Oncology (ASCO), the Multinational Association of Supportive Care in Cancer (MASCC) and the European Society for Medical Oncology. These guidelines are given in Tables $3^{[15-17]}$ and $4^{[18,19]}$.

In various hospitals, different antiemetic guidelines are followed and proper utilization of these guidelines in hospitals is evaluated through drug utilization methods. Drug utilization evaluation (DUE) is a potential, ongoing, and systematic tool for the critical evaluation of utilization of $\operatorname{drug}(\mathrm{s})$ and to ensure that the medicines are used appropriately and rationally. It can be used to provide early signals of irrational and misuse of drugs, also used to enhance the appropriate use of drugs, improvement in quality control cycle and its continuous quality improvement ${ }^{[20-22]}$.

DUE can provide adequate insight into the rational use of drugs and can increase the awareness of how drugs are being used to treat various diseases. DUE is most meaningful in continuous evaluation system and when it is followed over a period of time, trends in drug use can be recognised ${ }^{[20]}$. Researchers can estimate

TABLE 1: GRADING OF CHEMOTHERAPY-INDUCED NAUSEA AND VOMITING[13]

\begin{tabular}{|c|c|c|c|c|c|}
\hline & Grade 1 & Grade 2 & Grade 3 & Grade 4 & Grade 5 \\
\hline Nausea & $\begin{array}{l}\text { Loss of appetite } \\
\text { without alteration in } \\
\text { eating habits }\end{array}$ & $\begin{array}{l}\text { Oral intake decreased without } \\
\text { significant weight loss, } \\
\text { dehydration or malnutrition; } \\
\text { iv fluids indicated for less } \\
\text { than } 24 \mathrm{~h}\end{array}$ & $\begin{array}{c}\text { Inadequate oral caloric or } \\
\text { fluid intake; iv fluids, tube } \\
\text { feeding or TPN indicated for } \\
>2 \mathrm{~h}\end{array}$ & $\begin{array}{l}\text { Life- } \\
\text { threatening } \\
\text { consequences }\end{array}$ & Death \\
\hline Vomiting & 1 episode in $24 \mathrm{~h}$ & $\begin{array}{l}\text { 2-5 episodes in } 24 \mathrm{~h} \text {; iv fluids } \\
\text { indicated for less than } 24 \mathrm{~h}\end{array}$ & $\begin{array}{l}>6 \text { episodes in } 24 \mathrm{~h} \text {; iv fluids } \\
\text { or TPN indicated for }>24 \mathrm{~h}\end{array}$ & $\begin{array}{l}\text { Life threatening } \\
\text { consequences }\end{array}$ & Death \\
\hline
\end{tabular}


the rational, overuse and misuse of drugs and or alternatives, and the extent of drugs use. It can be used to analyze and compare utilization pattern of $\operatorname{drug}(\mathrm{s})$ for the treatment of disease(s) with current guidelines and recommendations. Inconsistent use with reference to guideline recommendations in treating disease

TABLE 2: RISK CATEGORY OF ANTICANCER DRUGS ${ }^{[14]}$

\begin{tabular}{|c|c|c|c|}
\hline High risk & Moderate risk & Low risk & Minimal risk \\
\hline $\begin{array}{l}\text { Carmustine } \\
\text { Cisplatin } \\
\text { Cyclophosphamide } \\
\text { Dacarbazine } \\
\text { Mechlorethamine }\end{array}$ & $\begin{array}{c}\text { Alemtuzumab } \\
\text { Azacitidine } \\
\text { Bendamustine } \\
\text { Carboplatin } \\
\text { Clofarabine } \\
\text { Cyclophosphamide } \\
\text { Cytarabine } \\
\text { Daunorubicin } \\
\text { Doxorubicin } \\
\text { Epirubicin } \\
\text { Idarubicin } \\
\text { Cyclophosphamide } \\
\text { Imatinib } \\
\text { Temozolomide } \\
\text { Vinorelbine } \\
\text { Ifosfamide } \\
\text { Irinotecan } \\
\text { Oxaliplatin }\end{array}$ & $\begin{array}{c} \\
\text { Bortezomib } \\
\text { Cabazitaxel } \\
\text { Catumaxomab } \\
\text { Cetuximab } \\
\text { Cytarabine } \\
\text { Docetaxel } \\
\text { Doxorubicin (liposomal) } \\
\text { Etoposide } \\
\text { 5-Fluorouracil } \\
\text { Gemcitabine } \\
\text { Ixabepilone } \\
\text { Paclitaxel }\end{array}$ & $\begin{array}{c}\text { Bevacizumab } \\
\text { Chlorambucil } \\
\text { Bleomycin } \\
\text { Erlotinib } \\
\text { Busulfan } \\
\text { Gefitinib } \\
\text { Cladribine } \\
\text { Hydroxyurea } \\
\text { Vinorelbine } \\
\text { Fludarabine } \\
\text { Rituximab } \\
\text { Vinblastine } \\
\text { Vincristine } \\
\text { Mustard } \\
\text { Methotrexate } \\
\text { Sorafenib }\end{array}$ \\
\hline
\end{tabular}

High risk- nearly always causes nausea and vomiting, moderate risk- usually causes nausea and vomiting, low risk- sometimes causes nausea and vomiting and minimum risk- rarely causes nausea and vomiting

TABLE 3: NCCN AND ASCO ANTIEMETIC GUIDELINES ${ }^{[15-17]}$

\begin{tabular}{|c|c|}
\hline $\begin{array}{l}\text { Emetic-risk } \\
\text { Category }\end{array}$ & ASCO guidelines \\
\hline & $\begin{array}{l}\text { Three-Drug combination of } 5 \mathrm{HT}_{3} \text { receptor } \\
\text { antagonist, dexamethasone, and aprepitant } \\
\text { recommended before chemotherapy }\end{array}$ \\
\hline High (>90 \%) risk & $\begin{array}{l}\text { For patients receiving cisplatin and all other } \\
\text { agents of high emetic risk, the two drug } \\
\text { combination of dexamethasone and aprepitant } \\
\text { recommended for prevention of delayed emesis }\end{array}$ \\
\hline & $\begin{array}{c}\text { For patients receiving an anthracycline } \\
\text { and cyclophosphamide, the three drug } \\
\text { combination of a } 5 \mathrm{HT}_{3} \text { receptor antagonist, and } \\
\text { dexamethasone, and aprepitant recommended } \\
\text { before chemotherapy; single agent aprepitant } \\
\text { recommended on days } 2 \text { and } 3 \text { for prevention of } \\
\text { delayed emesis }\end{array}$ \\
\hline
\end{tabular}

Moderate $(30 \%$ to $90 \%)$ risk

Low

$(10-30 \%)$ risk

Minimal (<10\%)

risk
For patients receiving other chemotherapies of moderate emetic risk, the two drug combination of a $5 \mathrm{HT}_{3}$ receptor antagonist, and dexamethasone recommended before chemotherapy; single agent dexamethasone or a $5 \mathrm{HT}_{3}$ receptor antagonist suggested on days 2 and 3 for prevention of delayed emesis

Dexamethasone $(8 \mathrm{mg}$ ) suggested; no routine preventive use of antiemetics for delayed emesis suggested

No antiemetic administered routinely before or after chemotherapy
NCCN Guidelines

Before chemotherapy, a $5 \mathrm{HT}_{3}$ receptor antagonist

(ondansetron, granisetron, dolasetron or

palonosetron*) dexamethasone $12 \mathrm{mg}$ and aprepitant (125 mg) recommended, with or without lorazepam

For prevention of delayed emesis, dexamethasone

( $8 \mathrm{mg}$ ) on days $2-4$ plus aprepitant $(80 \mathrm{mg}$ ) on days 2

and 3 recommended, with or without lorazepam on days 2-4

For patients receiving an anthracycline and cyclophosphamide and selected patients receiving other chemotherapies of moderate emetic risk (e.g., carboplatin, cisplatin, doxorubicin, epirubicin, ifosfamide, irinotecan, or methotrexate), a $5 \mathrm{HT}_{3}$ receptor antagonist (ondansetron, granisetron, dolasetron or palonosetron*) dexamethasone (12 $\mathrm{mg})$ and aprepitant $(125 \mathrm{mg})$ recommended, with or without lorazepam, before chemotherapy; for other patients, aprepitant is not recommended

For prevention of delayed emesis, dexamethasone $(8 \mathrm{mg})$ or a $5 \mathrm{HT}_{3}$ receptor antagonist on days 2-4 or, if used on day 1 , aprepitant $(80 \mathrm{mg})$ on days 2 and 3 with or without dexamethasone $(8 \mathrm{mg})$ on days $2-4$, recommended, with or without lorazepam on days 2-4

Metoclopramide, with or without diphenhydramine; dexamethasone $(12 \mathrm{mg})$; or prochlorperazine recommended, with or without lorazepam

No routine prophylaxis; consider using antiemetics listed under primary prophylaxis as treatment

NCCN: National Comprehensive Cancer Network, ASCO: American Society of Clinical Oncology 
TABLE 4: MASCC/ESMO ANTIEMETICS GUIDELINE[18,19]

\begin{tabular}{|c|c|c|c|c|c|c|c|c|}
\hline \multirow[t]{2}{*}{ Group } & \multicolumn{2}{|c|}{ High } & \multicolumn{2}{|l|}{ Moderate } & \multicolumn{2}{|c|}{ Low } & \multicolumn{2}{|c|}{ Minimal } \\
\hline & $\begin{array}{l}\text { Acute } \\
\text { CINV }\end{array}$ & $\begin{array}{l}\text { Delayed } \\
\text { CINV }\end{array}$ & $\begin{array}{l}\text { Acute } \\
\text { CINV }\end{array}$ & $\begin{array}{l}\text { Delayed } \\
\text { CINV }\end{array}$ & $\begin{array}{l}\text { Acute } \\
\text { CINV }\end{array}$ & $\begin{array}{c}\text { Delayed } \\
\text { CINV }\end{array}$ & $\begin{array}{l}\text { Acute } \\
\text { CINV }\end{array}$ & $\begin{array}{c}\text { Delayed } \\
\text { CINV }\end{array}$ \\
\hline MASCC & $\begin{array}{c}5-\mathrm{HT}_{3} \mathrm{RA} \\
\text { +dexamethasone } \\
\text { +aprepitant }\end{array}$ & $\begin{array}{l}\text { Dexamethasone } \\
\text { +aprepitant }\end{array}$ & $\begin{array}{c}\text { Anthracycline/ } \\
\text { cyclophosphamide } \\
5-\mathrm{HT}_{3} \mathrm{RA}+\text { dexamethasone } \\
\text { +aprepitant } \\
\text { Other than anthracycline/ } \\
\text { cyclophosphamide } \\
5-\mathrm{HT}_{3} \mathrm{RA}+\text { dexamethasone } \\
\text { +aprepitant }\end{array}$ & $\begin{array}{l}\text { Aprepitant or } \\
\text { dexamethasone } \\
\text { Dexamethasone, } \\
5-\mathrm{HT}_{3} \mathrm{RA} \text { may } \\
\text { be used as an } \\
\text { alternative }\end{array}$ & $\begin{array}{l}\text { Dexamet } \\
\text { hasone }\end{array}$ & a & a & $a$ \\
\hline
\end{tabular}

5- $\mathrm{HT}_{3}$ RA- 5-hydroxytryptamine receptor antagonist; a- as required, MASCC: Multinational Association of Supportive Care in Cancer, ESMO: European Society for Medical Oncology

might adversely affect patients' QoL and also cause huge economic burden ${ }^{[22]}$. Hence, this study was aimed to evaluate the antiemetic guidelines consistency and the effectiveness of antiemetics in controlling CINV in cancer chemotherapy patients.

\section{MATERIALS AND METHODS}

A study was carried out in chemotherapy patients who had completed their first chemotherapy cycle in the department of haemato-oncology of an 800 bed teaching hospital from September 2016 to August 2018. A total of 1725 patients who received antiemetics along with cancer chemotherapy were included in this study after obtaining their informed consent. Patients receiving both chemo and radiation therapy were excluded from the study.

\section{Study protocol:}

The study participants were categorized into 2 groups, the guideline-consistent chemotherapy prophylaxis group (GCCP) and the guideline-inconsistent chemotherapy prophylaxis group (GICP) where patients received antiemetic prophylaxis as per the standard guidelines to control CINV. Further, based on the emetogenicity of chemotherapy regimen given, three groups were created, highly emetogenic chemotherapy (HEC), moderately emetogenic chemotherapy (MEC) and low emetogenic chemotherapy (LEC). For analysing emesis in cancer patients, the study group was categorized into those with acute emesis, delayed emesis, acute and delayed emesis, and no emesis. The study participant's data were collected from the oncology department. Data were transferred directly from the patient case sheets, treatment records and direct interview with the patients. Specially designed data entry form was used to collect patient's demographics, type of cancer regimen, antiemetics given and its emetogenicity, details of patient's NV frequency and its grading, comparison of the data with standard guidelines, failure rate of antiemetics. This study included all patients those who were undergoing low to high emetogenic chemotherapy regardless of the type of solid tumors. The intensity and severity of $\mathrm{NV}$ experienced by the patients in all types of emesis were recorded with the aid of nausea grading as well as NCCN, MASCC and ASCO guidelines. Statistical analysis was performed and the individual variables were expressed as percentages. The study proposal and methodology was approved by Institutional Ethics Committee wide number EC/AP/372/03/2015.

\section{RESULTS AND DISCUSSION}

This prospective study was aimed to evaluate antiemetic guidelines consistency and the effectiveness of antiemetics in controlling CINV in cancer chemotherapy patients. A total of 2400 cancer patients were admitted to the hospital for their treatment during the study period. Out of this, 675 patients were receiving both chemo and radiation therapy and were excluded from the study. Out of 1725 patients enrolled in the study, 914 (53\%) were female and 811 (47\%) were male. Sixty percent $(n=1035)$ patients were given the medication according to standard guidelines and $40 \%$ $(n=690)$ were not (Table 5). Regarding the emetogenic potential of the chemotherapy regimen, $52 \%(\mathrm{n}=897)$ patients were in HEC, $36 \%(n=621)$ patients in the MEC and the remaining $12 \%(n=207)$ patients were in LEC regimen. Among those patients received both chemotherapy and antiemetics, most of the patients $(\mathrm{n}=1409 ; 81.68 \%)$ were found without emesis, $8.35 \%(\mathrm{n}=144)$ were with acute emesis, $7.65 \%$ $(\mathrm{n}=132)$ were in delayed emesis, $2.32 \%(\mathrm{n}=40)$ were both in acute and delayed emesis. Based on nausea grading, $8.29 \%(n=143)$ of the study population had 
grade-1 nausea, $4.35 \%(\mathrm{n}=75)$ grade- 2 nausea, $3.01 \%$ $(\mathrm{n}=52)$ grade -3 and $2.67 \%(\mathrm{n}=46)$ experienced grade- 4 nausea, however $81.68 \%(\mathrm{n}=1409)$ did not report any nausea. Readmission to the hospital with complaints of nausea or vomiting within a week was considered as the failure of therapy. In this study, $10 \%(n=173)$ of patients fall under failure of therapy and $90 \%(n=1552)$ in no failure of therapy group. The details are presented in Table 5.

The total population was categorized into two groups as GCCP and GICP groups. Among 1725 patients enrolled, 552 (32\%) female and $483(28 \%)$ male were compliant to the standard treatment guidelines while $362(21 \%)$ female and $328(19 \%)$ male patients were noncompliant to these standard guidelines. As per the emetogenicity of cancer chemotherapy, among the HEC group 518 (30\%) patients fall in GCCP and 379 $(21.97 \%)$ were fall in GICP group. In case of MEC and LEC, the patients complied with chemotherapy guidelines were $356(20.64 \%)$ and 161 (9.33\%), respectively, whereas in the noncompliant group it was $265(15.36 \%)$ and $46(2.67 \%)$, respectively.

Comparing the guideline compliance with the type of emesis, $23(1.33 \%)$ patients in the GCCP and $121(7.01 \%)$ patients in GICP showed acute emesis, $17(0.99 \%)$ patients in GCCP and $115(6.67 \%)$ in GICP group had delayed emesis, whereas $6(0.35 \%)$ patients in GCCP and 34 (1.97\%) patients in GICP had acute and delayed emesis. Most of the patients who did not complained of emesis included 989 $(57.33 \%)$ in GCCP and 420 (24.35\%) in GICP groups. On comparing the failure rate and guideline consistency, the study showed that $9.68 \%(n=167)$ patients in GICP and only $0.35 \%(n=6)$ in GCCP were readmitted to the hospital with complaints of second grade to fourth grade nausea or vomiting. However, most ( $\mathrm{n}=1029 ; 59.65 \%)$ of the GCCP patients have not had readmission to the hospital with any vomiting complaints. The details are presented in Table 6 .

Among the $782(45.33 \%)$ patients who received HEC alone, 144 (8.35\%) received monotherapy and $638(36.98 \%)$ received combination therapy. In monotherapy, dacarbazine, cisplatin and cyclophosphamide were prescribed to 52,75 , and 17 patients, respectively. In combination therapy, cisplatin plus dacarbazine and cisplatin plus cyclophosphamide plus dacarbazine were given in 201 $(11.65 \%)$ and $437(25.34 \%)$ patients, respectively. One hundred and fifty $(8.69 \%)$ patients received both HEC
TABLE 5: DISTRIBUTION OF STUDY POPULATION

\begin{tabular}{|c|c|c|}
\hline Group & $\begin{array}{l}\text { Number of patients } \\
\qquad(n=1725)\end{array}$ & Percent \\
\hline $\begin{array}{l}\text { Gender: } \\
\text { Male }\end{array}$ & 811 & 47.01 \\
\hline Female & 914 & 52.99 \\
\hline $\begin{array}{l}\text { Guideline consistency: } \\
\text { Guideline consistent } \\
\text { chemotherapy prophylaxis }\end{array}$ & 1035 & 60 \\
\hline $\begin{array}{l}\text { Guideline inconsistent } \\
\text { chemotherapy prophylaxis }\end{array}$ & 690 & 40 \\
\hline $\begin{array}{l}\text { Emetogenicity: } \\
\text { Highly emetogenic } \\
\text { chemotherapy }\end{array}$ & 897 & 52 \\
\hline $\begin{array}{l}\text { Moderately emetogenic } \\
\text { chemotherapy }\end{array}$ & 621 & 36 \\
\hline $\begin{array}{l}\text { Low emetogenic } \\
\text { chemotherapy }\end{array}$ & 207 & 12 \\
\hline Types of emesis received: & & \\
\hline Acute & 144 & 8.35 \\
\hline Delayed & 132 & 7.65 \\
\hline Acute and delayed & 40 & 2.32 \\
\hline No emesis & 1409 & 81.68 \\
\hline $\begin{array}{l}\text { Nausea grading among the } \\
\text { study population: } \\
\text { Grade } 1\end{array}$ & 143 & 8.29 \\
\hline Grade 2 & 75 & 4.35 \\
\hline Grade 3 & 52 & 3.01 \\
\hline Grade 4 & 46 & 2.67 \\
\hline No nausea & 1409 & 81.68 \\
\hline Failure rates: & & \\
\hline Yes & 173 & 10.03 \\
\hline No & 1552 & 89.97 \\
\hline
\end{tabular}

Failure meaning antiemetics readministered within one week

TABLE 6: DISTRIBUTION OF STUDY POPULATION BASED ON GUIDELINES CONSISTENCY $(n=1725)$

\begin{tabular}{lcc}
\hline \multirow{2}{*}{ Category } & \multicolumn{2}{c}{ Groups, number of patients (\%) } \\
\cline { 2 - 3 } & GCCP, 1035, (60 \%) GICP, 690, (40 \%) \\
\hline Gender: & $483(28.00)$ & $328(19.01)$ \\
Male & $552(32.00)$ & $362(20.99)$ \\
Emetogenale & & \\
HEC & $518(30.03)$ & $379(21.97)$ \\
MEC & $356(20.64)$ & $265(15.36)$ \\
LEC & $161(9.33)$ & $46(2.67)$ \\
Types of emesis: & $23(1.33)$ & $121(7.01)$ \\
Acute & $17(0.99)$ & $115(6.67)$ \\
Delayed & $6(0.35)$ & $34(1.97)$ \\
Acute and delayed & $989(57.33)$ & $420(24.35)$ \\
No emesis & $6(0.35)$ & $167(9.68)$ \\
Failure rates: & $1029(59.65)$ & $523(30.32)$ \\
Yes &
\end{tabular}

HEC- Highly emetogenic chemotherapy, MEC- moderately emetogenic chemotherapy LEC- low emetogenic chemotherapy, failure is antiemetics readministered within one week 
and MEC concurrently, which was cyclophosphamide plus doxorubicin. Five hundred and forty-six $(31.65 \%)$ patients received MEC as monotherapy, among these 115 (6.67 \%) patients received doxorubicin, 310 $(17.97 \%)$ received carboplatin and 121 (7.01\%) received oxaliplatin. There were $58(3.36 \%)$ patients received both HEC and LEC as combination therapy, which was cyclophosphamide plus methotrexate. Moreover, 189 (10.96\%) patients received LEC as monotherapy, among them $104(6.03 \%)$ patients received paclitaxel, 34 (1.97 \%) each received docetaxel and gemcitabine and $17(0.99 \%)$ received methotrexate. The details are given in Table 7.

There were group of antiemetics given to control the CINV. Among the 1725 patients, 730 $(42.32 \%)$ received 3 antiemetics, 788 (45.68\%) received 2 antiemetics as combination therapy and $207(12 \%)$ received an antiemetic as monotherapy. Five hundred and forty $(31.31 \%)$ patients received palonosetron+dexamethasone+aprepitant, $270 \quad(15.65 \%) \quad$ patients received palonosetron+dexamethasone, $190 \quad(11.01 \%)$ received dexamethasone + palonosetron+olanzapine, whereas $518 \quad(30.03 \%)$ patients received dexamethasone+ondansetron combination. Moreover, $161(9.33 \%)$ patients received dexamethasone and only 46 (2.67\%) received ondansetron as monotherapy. The details of antiemetics prescribed are presented in Table 8 .

CINV has a major impact on the daily lives of cancer patients and causes serious harm to the body. The failure of antiemetic therapy will adversely affect the patients
QoL. CINV can be prevented or reduced by using appropriate antiemetic therapy. The most important factors that determine the effect of antiemetics in CINV are narrow patient selection, well-defined protocolbased chemotherapy, and suitable antiemetic regimen.

Since 1960s, studies of antiemetics in cancer patients have been a great field of medical research, but CINV is still a major issue in cancer patients. Substantial progress in the understanding of the mechanism of CINV stimulated the researchers to develop new antiemetics such as antidopaminergics, corticosteroids, 5-HT3 receptor antagonists (5-HT3RA), NK1 receptor antagonists and also the new antipsychotic agent olanzapine. Development of these drugs has led to the establishment of numerous international guidelines for the prevention and treatment of $\mathrm{CINV}^{[23]}$.

In this prospective observational study, patients were evaluated after their first chemotherapy cycle to assess the efficacy and outcome of antiemetics to reduce CINV. A total of 1725 patients received anticancer chemotherapy and among them HEC ( $\mathrm{n}=897 ; 52 \%)$ was given to a majority of patients followed by MEC $(\mathrm{n}=621 ; 36 \%)$, and LEC $(\mathrm{n}=207 ; 12 \%)$ chemotherapy.

In this study, majority of the participants were female $(\mathrm{n}=914,53 \%)$, which is similar to the studies reported by De Tursi et al. ${ }^{[24]}$ and Elizabeth et al. ${ }^{[25]}$ in which female participants were 65 and $79 \%$, respectively. In the gender wise distribution of cancer, female cancer patients are more due to their lifestyle and food habits, which led to breast and cervical cancer. In this study most of the patients were treated with

\section{TABLE 7: COMMONLY PRESCRIBED CHEMOTHERAPY IN THE STUDY POPULATION}

\begin{tabular}{|c|c|c|c|}
\hline Emetogenicity & Name of chemotherapy & Number of patients $(n=1725)$ & Percent \\
\hline \multirow{5}{*}{ High emetogenic chemotherapy } & Dacarbazine & 52 & 3.01 \\
\hline & Cisplatin & 75 & 4.35 \\
\hline & Cisplatin plus dacarbazine & 201 & 11.65 \\
\hline & $\begin{array}{c}\text { Cisplatin+ } \\
\text { cyclophosphamide+dacarbazine }\end{array}$ & 437 & 25.34 \\
\hline & Cyclophosphamide & 17 & 0.99 \\
\hline $\begin{array}{l}\text { High and moderate emetogenic } \\
\text { chemotherapy }\end{array}$ & Cyclophosphamide+doxorubicin & 150 & 8.69 \\
\hline \multirow{3}{*}{$\begin{array}{l}\text { Moderate emetogenic } \\
\text { chemotherapy }\end{array}$} & Doxorubicin & 115 & 6.67 \\
\hline & Carboplatin & 310 & 17.97 \\
\hline & Oxaliplatin & 121 & 7.01 \\
\hline $\begin{array}{l}\text { High and low emetogenic } \\
\text { chemotherapy }\end{array}$ & Cyclophosphamide+methotrexate & 58 & 3.36 \\
\hline \multirow{4}{*}{ Low emetogenic chemotherapy } & Paclitaxel & 104 & 6.03 \\
\hline & Docetaxel & 34 & 1.97 \\
\hline & Gemcitabine & 34 & 1.97 \\
\hline & Methotrexate & 17 & 0.99 \\
\hline
\end{tabular}


TABLE 8: ANTIEMETIC REGIMEN PRESCRIBED IN THE STUDY POPULATION $(\mathrm{N}=1725)$

\begin{tabular}{lcc}
\hline Antiemetic regimen & $\begin{array}{c}\text { Number of } \\
\text { patients }\end{array}$ & Percent \\
\hline $\begin{array}{l}\text { Antiemetics to treat HEC CINV: } \\
\text { Palonosetron+dexamethasone } \\
\text { +aprepitant }\end{array}$ & 540 & 31.31 \\
$\begin{array}{l}\text { Palonosetron+dexamethasone } \\
\text { Antiemetics to treat both HEC }\end{array}$ & 270 & 15.65 \\
$\begin{array}{l}\text { and MEC CINV: } \\
\text { Dexamethasone+palonosetron } \\
\text { +olanzapine }\end{array}$ & 190 & 11.01 \\
$\begin{array}{l}\text { Antiemetics to treat MEC CINV: } \\
\text { Dexamethasone+ondansetron }\end{array}$ & 518 & \\
$\begin{array}{l}\text { Antiemetics to treat LEC CINV: } \\
\text { Dexamethasone }\end{array}$ & & \\
\begin{tabular}{l} 
Ondansetron \\
\hline
\end{tabular} & 161 & 9.03 \\
& 46 & 2.67 \\
\hline
\end{tabular}

combination therapy. A combination of cisplatin plus cyclophosphamide plus dacarbazine was commonly used in the majority of patients followed by cisplatin plus dacarbazine, cyclophosphamide plus doxorubicin, and cyclophosphamide plus methotrexate. Most of the patients $(n=713)$ were treated with HEC agent cisplatin either as monotherapy or in combination therapy. This finding is similar to those reported by Debrix et al. ${ }^{[26]}$ and Hilarius et al. ${ }^{[27]}$, where most of the patients were treated with HEC. However this finding is not in agreement with that reported by Baburaj et al. ${ }^{[28]}$ and Aapro et al. ${ }^{[29]}$, where most of the patients were treated with doxorubicin and cyclophosphamide combination, as cisplatin-induced delayed CINV intensity peaks at 2-3 d and might last for few days after the administration of chemotherapy ${ }^{[30]}$. HEC was prescribed in higher proportion in GICP group than GCCP while MEC was prescribed in higher proportion in GCCP than GICP group.

In this study, adherence to NCCN, MASCC, and ASCO guidelines were higher with GCCP group when compared to the GICP group even though these guidelines have some differences among them. All guidelines provide clinicians with updated references and a list of recommendations developed based on the international experts opinion on optimum use of antiemetics. This finding is consistent with the studies by Aapro et al. ${ }^{[29]}$ and Gilmore et al. ${ }^{[31]}$ proved that the guideline adherence was higher with GCCP group than GICP patients.

As the chemotherapy and antiemetics were administered using NCCN, MASCC, and ASCO guidelines the number of patients with CINV was less in the GCCP group which evident that only $46(2.67 \%)$ patients in
GCCPhad any one type of emesis, whereas 270(15.65\%) patients in GICP group had either acute, delayed or acute and delayed emesis. Around $82 \%(n=1409)$ have not had any episode of NV during the study period. These findings strengthen the utilization of treatment guidelines for improved QoL of cancer patients. Within the guideline groups there was no significant difference between the types of emesis, which is similar to Bloechl et al. ${ }^{[32]}$ study where there is no difference between delayed and acute NV.

Antiemetics were considered for readministering within one-week period after the patient experience any acute or delayed emesis to control emesis and to find out the failure rate of antiemetic therapy in CINV. Among those 46 patients in GCCP and 270 patients in GICP groups with acute to acute and delayed emesis, 40 patients in GCCP and 103 patients in GICP group were observed with grade-1 NV and henceforth no antiemetics were readministered again in these patients. However, 167 patients in GICP and six patients in GCCP groups were found to have grade- 2 and above $\mathrm{NV}$, hence antiemetics were readministered to control the CINV, which indicate the higher failure rate $(10 \%)$ of antiemetics to control CINV. However, no iv fluids were indicated for these patients. The failure rate is more in current study GICP group (9.68 \%) compared to other studies where the failure rate is very negligible as the treatment was followed using standard guidelines NCCN, MASCC and ASCO ${ }^{[30,32]}$.

Among the 173 patients who fall under the category of failure of therapy, cisplatin at a dose of $70 \mathrm{mg} / \mathrm{m}^{2}$, cyclophosphamide $600 \mathrm{mg} / \mathrm{m}^{2}$, dacarbazine $100 \mathrm{mg} / \mathrm{m}^{2}$ and doxorubicin $60 \mathrm{mg} / \mathrm{m}^{2}$ produced CINV in majority of the patients. This finding is consistent with other studies that the delayed CINV is common in chemotherapy regimens that involved cisplatin, carboplatin, cyclophosphamide, and/or doxorubicin ${ }^{[30,33,34]}$.

The prevalence of guideline consistent CINV prophylaxis was higher, and there were no severe CINV among patients who received antiemetics based on the guidelines when compared to those who did not receive antiemetics based on the guidelines. Similar results were observed in Gilmore et al. ${ }^{[31]}$ study where no CINV was significantly higher in the GCCP than the GICP cohort (53.4 vs. $43.8 \%$ ). The study carried out by Aapro $^{[29]}$ also proved that complete response rate was higher in GCCP followers than GICP. Majority of the study participants were prescribed with palonosetron, 
dexamethasone and aprepitant combination as these drugs are more effective in controlling cisplatin induced NV. In many studies, antiemetics were mostly tested on patients who received cisplatin, a HEC and most HCP agree an agent that inhibit or reduces emesis after cisplatin therapy will be effective for other chemotherapeutic agents with high-to-moderate emetogenicity ${ }^{[33-35]}$.

Dexamethasone alone or in combination with 5-HT3RA and/or NK-1 receptor antagonist also recommended to alleviate $\mathrm{CINV}$ when patients receiving $\mathrm{HEC} /$ MEC. It is extensively recommended in all guidelines that corticosteroids are the most extensively studied and are widely available. Recent studies recommend dexamethasone for the management of delayed

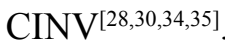

$\mathrm{NV}$ is the most common and frequently reported serious side effect of almost all anticancer agents and it adversely affect patients' daily functioning and health-related QoL. The introduction of 5HT3RA has a significant advancement in inhibiting CINV. Aprepitant, a drug which was introduced recently that selectively blocks the binding of substance-P at the NK-1 receptor in central nervous system, has been shown to have potential antiemetic activity over 5HT3RA, corticosteroid, dexamethasone, and also inhibit both acute and delayed emesis of HEC.

Clinical practice guidelines for the management of various diseases are being promoted for helping practitioners to take appropriate clinical decisions. In addition, enhance the effectiveness of drugs and reduces the health care costs. This study showed that the treatment for cancer patients was according to the standard guidelines. CINV particularly acute, delayed $\mathrm{NV}$ are continuing to be a significant problem for cancer patients with chemotherapy. In this study the guideline consistent group had complete response and control as less NV reported.

In the current study there were 316 patients had CINV and majority were inconsistent to the chemotherapy guidelines. However, the patients who consistent with chemotherapy guidelines have not had any emesis during and after their chemotherapy. This emphasizes the importance of following anticancer chemotherapy guidelines. Further, it proved that the patient consistent to GCCP (NCCN, ASCO and MASCC) received effective antiemetic therapy and therefore no much failure in GCCP group. However, there is $10 \%$ failure rate in GICP group in the current practice of the tertiary care teaching hospital in India. Hence this study accentuates the strict utilization and follow up of anticancer chemotherapy guidelines.

Even though the emetogenicity of anticancer drugs are widely accepted as the most common and important risk factor for CINV, it plays a major role in the appropriate selection of antiemetic therapy. This study findings also provide support for the use of GCCP to reduce the incidence of CINV in HEC, MEC and LEC. Moreover, it also indicated that there is a major benefit of using guideline consistent antiemetic therapy to achieve CINV end points in the acute and delayed phases. Hence, this study strongly encourages the healthcare professionals of the country to adhere with all anticancer chemotherapy guidelines for better health outcomes for patients.

\section{Acknowledgments:}

Authors acknowledge the staff and management of $\mathrm{KMCH}$ hospital and institutions for support and encouragement to carry out this work. Author contributions: conceptualization, GK and PS; methodology, GK; software, MK; validation, $\mathrm{NH}$, GK and PS; formal analysis, $\mathrm{MK}$; investigation, $\mathrm{NH}$; resources, $\mathrm{GK}$; data curation, $\mathrm{NH}$; writing, original draft preparation, GK; writing, review and editing, PS, DA and RV; visualization, MK, MA and MC; supervision, GK; project administration, NH. The authors thank the Deanship of Scientific Research at King Khalid University for providing adequate support.

\section{Conflict of interest:}

Authors declare no conflicts of interest.

\section{REFERENCES}

1. Cancer fact sheet. World Health Organization. 2018, [cited 2018 Jun 19]. Available from: http://www.who.int/newsroom/fact-sheets/detail/cancer.

2. Ananya M. Cancer Pathophysiology 2018, NEWS medical life sciences. [cited 2018 Aug 04]. Available from: https:// www.news-medical.net/health/Cancer-Pathophysiology.aspx.

3. Cancer 2018, Medlineplus. [updated 2018 Aug 28; cited 2018 Sep 04]. Available from: https://medlineplus.gov/cancer.html.

4. Cancer 2018, Medicine Net. [cited 2018 Aug 06]. Available from: https://www.medicinenet.com/cancer/article.htm.

5. Medical Care of the Dying. 4th ed. Canada: Victoria Hospice Society. 2006. p. 319.

6. Types of cancer treatment. National Cancer Institute 2018. [updated 2017 April 6; cited 2018 Sep 04]. Available from: https://www.cancer.gov/about-cancer/treatment/types.

7. Colomer A, Alba E, Gonzalez-Martin A, Paz-Ares L, Martin 
M, Llombart A, et al. Treatment of cancer with oral drugs: a position statement by the Spanish Society of Medical Oncology (SEOM). Ann Oncol 2010;21(2):195-8.

8. Sachdeva PD, Patel BG, Drug utilization studies- scope and future perspective. Int J Pharm Biol Res 2010;1:11-17.

9. NCCN clinical practice guidelines in oncology. [updated 2018 June 11; cited 2018 Sep 04]. Available from: https://www. nccn.org/professionals/physician_gls/pdf/antiemesis.pdf.

10. Morran C, Smith DC, Anderson DA, McArdle CS. Incidence of nausea and vomiting with cytotoxic chemotherapy: a prospective randomized trial of antiemetics. Br Med $\mathrm{J}$ 1979;1(6174):1323-4.

11. Salihah N, Mazlan N, Lua PL. Chemotherapy-induced nausea and vomiting: exploring patients' subjective experience. J Multidiscip Healthc 2016;9:145-51.

12. Sommariva S, Pongiglione $\mathrm{B}$, Tarricone $\mathrm{R}$. Impact of chemotherapy-induced nausea and vomiting on health-related quality of life and resource utilization: A systematic review. Crit Rev Oncol Hematol 2016;99:13-36.

13. Jeremy B, James C. ASWCS antiemetic guidelines. For adult patients receiving chemotherapy and radiotherapy. [updated 2012 February; cited 2018 Sep 1]. Available from: https:// docplayer.net/43887862-Aswcs-antiemetic-guidelines-foradult-patients-receiving-chemotherapy-and-radiotherapy. html.

14. Emetogenic risk of chemotherapy and biotherapy agents. [cited 2018 Aug 20]. Available from: https://www.ons.org/ sites/default/files/emetogenicity_tool.pdf.

15. NCCN clinical practice guidelines in oncology (NCCN Guidelines ${ }^{\circledR}$ ) and the NCCN drugs \& biologics compendium (NCCN Compendium ${ }^{\circledR}$ ) for antiemesis. [cited 2018 Aug 22]. Available from: https://www.nccn.org/about/news/ebulletin/ ebulletindetail.aspx?ebulletinid $=6$.

16. Hesketh PJ, Kris MG, Basch E, Bohlke K, Barbour SY, ClarkSnow RA, et al. Antiemetics: American Society of Clinical Oncology clinical practice guideline update. J Clin Oncol 2017;35(28):3240-61.

17. A guide to emetic risk, chemotherapy, and CINV. [cited 2018 Aug 22]. Available from: http://www.aloxi.com/docs/pdf/ emetic-risk-guide.pdf.

18. Jordan K, Sippel C, Schmoll HJ. Guidelines for antiemetic treatment of chemotherapy-induced nausea and vomiting: past, present, and future recommendations. Oncologist 2007;12(9):1143-50.

19. MASCC/ESMO antiemetic guideline. [updated 2016 March; cited 2018 Jun 30]. Available from: https://www.mascc. org/assets/Guidelines-Tools/mascc_antiemetic_guidelines_ english_v.1.2.1.pdf.

20. Tavakoli-Ardakani M, Eshraghi A, Hajhossein TA, Salamzadeh J. A Drug utilization evaluation study of amphotericin b in neutropenic patients in a teaching hospital in Iran. Iran J Pharm Res 2012;11:151-6.

21. Mousavi S, Behi M, Taghavi MR, Ahmadvand A, Ziaie S, Moradi M. Drug utilization evaluation of imipenem and intravenous ciprofloxacin in a teaching hospital. Iran J Pharm Res 2013;12:161-7.

22. Introduction to drug utilization research. WHO. [cited 2018
Aug 15]. Available from: http://apps.who.int/medicinedocs/ en/d/Js4876e/4.6.html.

23. Navari RM. Chemotherapy-Induced Nausea and Vomiting: Molecular Mechanisms and Clinical Approaches. In: de Mello R, Tavares A, Mountzios G, editors. International Manual of Oncology Practice. Berlin, Germany: Springer, Cham; 2015.

24. De Tursi M, Carella C, Tomao S, Cinieri S, Lorusso V, Marchetti $\mathrm{P}$, et al. Chemotherapy-induced nausea and vomiting in Italian cancer centers: results of CINVDAY, a prospective, multicenter study. Tumori 2014;100(6):e309-13.

25. Elizabeth PP, Ahana B, Babitha AE, Apollo J, Sheik HS, Mohanraj KP, et al. A study on evaluation of anti-emetics in the prevention of chemotherapy induced nausea and vomiting in cancer patients in a tertiary care hospital. Indian J Pharm Pract 2017; 10:8-13.

26. Debrix I, Flahault A, Becker A, Schwartz L, Kanfer A, Milleron B. Impact of guideline implemented in a Paris university hospital: application to the use of antiemetics by cancer patients. Br J Clin Pharmacol 1999;48(4):616-22.

27. Hilarius DL, Kloeg PH, van der Wall E, van den Heuvel JJ, Gundy CM, Aaronson NK. Chemotherapy-induced nausea and vomiting in daily clinical practice: a community hospitalbased study. Support Care Cancer 2012;20:107-17.

28. Baburaj G, Abraham AM, George L, Shetty V, Thempalangad RM, Rajesh KS, et al. A study on utilization and evaluation of antiemetics in chemotherapy-induced nausea and vomiting. Indian J Med Paediatr Oncol 2017:38(3);334-9.

29. Aapro M, Molassiotis A, Dicato M, Pelaez I, RodriguezLescure A, Pastorelli D, et al, on behalf of the PEER investigators. The effect of guideline-consistent antiemetic therapy on chemotherapy - induced nausea and vomiting (CINV): The Pan European Emesis Registry (PEER). Ann Oncol 2012;23(8):1986-92.

30. Rudolph MN. Treatment of Breakthrough and Refractory Chemotherapy-Induced Nausea and Vomiting. BioMed Res Int 2015;2015:595894.

31. Gilmore JW, Peacock NW, Gu A, Szabo S, Rammage $\mathrm{M}$, Sharpe $\mathrm{J}$, et al. Antiemetic guideline consistency and incidence of chemotherapy-induced nausea and vomiting in US community oncology practice: INSPIRE study. J Oncol Pract 2014;10:68-73.

32. Bloechl-Daum B, Deuson RR, Mavros P, Hansen M, Herrstedt J. Delayed nausea and vomiting continue to reduce patient's quality of life after highly and moderately emetogenic chemotherapy despite antiemetic treatment. J Clin Oncol 2006;24(27):4472-8.

33. Skoetz N, Haque M, Weigl A, Kuhr K, Monsef I, Becker I, et al. Antiemetics for adults for prevention of nausea and vomiting caused by moderately or highly emetogenic chemotherapy: a network meta-analysis. Syst Rev 2017;9:CD012775.

34. Mustian KM, Devine K, Ryan JL, Janelsins MC, Sprod LK, Peppone LJ, et al. Treatment of Nausea and Vomiting During Chemotherapy. US Oncol Hematol 2011;7(2):91-7.

35. Chan VT, Yeo W. Antiemetic therapy options for chemotherapy-induced nausea and vomiting in breast cancer patients. Breast Cancer 2011;3:151-60. 